\title{
FAKTOR-FAKTOR YANG BERHUBUNGAN DENGAN KEJADIAN DIARE PADA ANAK BALITA DI WILAYAH PESISIR KELURAHAN LAPULU KECAMATAN ABELI KOTA KENDARI
}

\section{Factors Related To The Event Of Diarrhea In Children In The Coastal Area Of Lapulu Village Abeli District Kendari City}

\author{
Fitri Rachmillah Fadmi, Andi Mauliyana, Zatyani Muthia Mangidi \\ Program Studi Sarjana Kesehatan Masyarakat \\ Universitas Mandala Waluya \\ (fitri.rachmillahfadmi@gmail.com, 085241545007)
}

\begin{abstract}
ABSTRAK
Diare merupakan gangguan buang air besar yang ditandai buang air besar lebih dari 3 kali sehari dengan konsentrasi tinja cair disertai darah. Berdasarkan data profil Puskesmas Abeli pada tahun 2016 terdapat 286 balita yang menderita diare kemudian pada tahun 2017 terdapat 269 balita yang menderita diare dan pada tahun 2018 terdapat 160 balita yang menderita diare. Tujuan penelitian ini untuk mengetahui faktor-faktor yang berhubungan dengan kejadian penyakit diare pada Balita di wilayah Pesisir Kelurahan Lapulu Kecamatan Abeli Kota Kendari. Jenis penelitian yang digunakan adalah analitik dengan pendekatan observasional yang menggunakan rancangan Cross Sectional Study. Populasi dalam penelitian ini berjumlah 96 balita. Jumlah sampel sebanyak 49 responden, dengan teknik penarikan sampel menggunakan Simple Random Sampling. Metode analisis menggunakan uji Chi-Square dan uji Phi. Hasil penelitian menunjukan bahwa ada hubungan sedang antara pengetahuan ibu $p$-value $(0,012<\alpha 0,05)$, ada hubungan sedang antara penyediaan air bersih $p$-value $(0,003<\alpha 0,05)$, dan ada hubungan sedang antara jamban keluarga $p$-value $(0,004<\alpha 0,05)$ dengan kejadian penyakit diare pada Balita di wilayah Pesisir Kelurahan Lapulu Kecamatan Abeli Kota Kendari.
\end{abstract}

Kata Kunci : Kejadian diare, pengetahuan, penyediaan air bersih, jamban keluarga

\section{ABSTRACT}

Diarrhea is a bowel disorder characterized by bowel movements more than 3 times a day with a concentration of liquid and blood. Based on the profile data of Puskesmas Abeli in 2016, 286 children under five suffered from diarrhea, then in 2017, 269 children under five suffered from diarrhea, and in 2018, 160 children under five had diarrhea. The purpose of this study was to determine the factors associated with the incidence of diarrhea disease in toddlers in the coastal area of Lapulu Village, Abeli District, Kendari City. This type of research is analytic with an observational approach using a cross-sectional study design. The population in this study amounted to 96 toddlers. The number of samples was 49 respondents, with the sampling technique using simple random sampling. The method of analysis used the chi-square test and the phi test. The results showed that there was a moderate relationship between maternal knowledge p-value $(0,012<\alpha 0,05)$, there was a moderate relationship between clean water supply $p$-value $(0,003<\alpha 0,05)$, and there was a moderate relationship between $p$-value family latrines. value $(0,004<\alpha 0,05)$ with the incidence of diarrhea in toddlers in the coastal area of Lapulu Village, Abeli District, Kendari City.

Keywords: Incidence of diarrhea, knowledge, clean water supply, family toilet 


\section{PENDAHULUAN}

Diare merupakan gangguan buang air besar yang ditandai buang air besar lebih dari 3 kali seharu dengan konsentrasi tinja cair, dapat disertai dengan darah. Penyakit diare masih menjadi masalah globar dengan derajat kesakutan dan kematian yang tinggi di berbagai negara terutama negara berkembang, dan juga sebagai salah satu penyebab utama tingginya angka kesakitan dan kematian anak di dunia. Secara umum diperkirakan lebih dari 10 juta anak berusia kurang dari 5 tahun meninggal setiap tahunnya di dunia dimana sekitar 20\% meninggal karena unfeksi diare. ${ }^{1}$

Menurut WHO diare adalah kejadian buang air besar dengan konsistensi lebih cair dari biasanya, dengan frekuensi tiga kali atau lebih dalam periode 24 jam. Diare merupakan penyakit berbasis lingkungan yang disebabkan oleh infeksi mikroorganisme meliputi bakteri, virus, parasit, protozoa, dan penularannya secara fekal-oral. Diare dapat mengenai semua kelompok umur baik balita, anak-anak dan orang dewasadengan berbagai golongan sosial. Diare merupakan penyebab utama morbiditas dan mortalitas di kalangan anak-anak kurang dari 5 tahun. Secara global terjadi peningkatan kejadian diare dan kematian akibat diare pada balita dari tahun 2015-2017. Pada tahun 2015, diare menyebabkan sekitar 688 juta orang sakit dan 499.000 kematian di seluruh dunia tejadi pada anak-anak dibawah 5 tahun.Data WHO (2017) menyatakan, hampir 1,7 miliar kasus diare terjadi pada anak dengan angka kematian sekitar 525.000 pada anak balita tiap tahunnya. $^{2}$
Berdasarkan profil Kesehatan Indonesia Target cakupan pelayanan penderita Diare semua umur (SU) yang datang ke sarana kesehatan adalah $10 \%$ dari perkiraan jumlah penderita Diare SU (Insidensi Diare SU dikali jumlah penduduk di satu wilayah kerja dalam waktu satu tahun). Tahun 2017 jumlah penderita diare SU yang dilayani di sarana kesehatan sebanyak 3.176.079 penderita dan terjadi peningkatan pada tahun 2018 yaitu menjadi 4.274 .790 penderita atau $60,4 \%$ dari perkiraan diare di sarana kesehatan. Insiden diare semua umur secara nasional adalah 270/1.000 penduduk. ${ }^{3}$

Berdasarkan data Dinas Kesehatan Provinsi Sulawesi Tenggara tahun 2016 terdapat 41.071 penderita diare dari 2.468 .678 jiwa jumlah penduduk,tahun 2017 terdapat 35.846 penderita diare dari 2.591.159 jiwa jumlah penduduk, dan pada tahun 2018 mengalami peningkatan menjadi 39.913 penderita diaredari 2.637.447 jiwa jumlah penduduk. ${ }^{4}$ Berdasarkan data Puskesmas Abeli tahun 2016, terdapat 286 balita yang menderita diare, tahun 2017terdapat 269 balita yang menderita diare dan pada tahun 2018, terdapat 160 balita yang menderita diare, tahun 2019 periode Januari-Juni terdapat 96 balita yang menderita diare. ${ }^{5}$

Pengetahuan merupakan domain yang sangat penting untuk terbetuknya tindakan seseorang, dimana pengetahuan yang cukup akan membuat seseorang melalkukan tindakan yang baik dan sehat untuk dirinya dan keluarganya. Namun sebaliknya orang yang tidak memiliki pengetahuan yang cukup 
cenderung akan melakukan tindakan yang kurang sehat, seperti tidak mencuci tangan sebelum makan, membuang tinja di bahu sungai atau laut. Hal ini menyababkan risiko terjadinya penyakit diare.

Penyedian air bersih dan keberadaan jamban keluarga merupakan hal yang mampu menurunkan angka diare, namun untuk wilayah pesisir penyediaan air bersih serta keberadaan jamban di wilayah pesisir masih sulit, dan hal ini yang menimbulkan risiko diare pada balita bahkan untuk semua umur ditambah tingakat pengetahuan yang masih kurang tentang penularan proses seseorang terkena penyakit diare. Penyediaan Air Bersih $(\mathrm{PAB})$ memiliki risiko terhadap kejadian diare. Kemudian tidak adanya jamban keluarga dapat membuat seseorang menderita penyakit diare, karena seseorang yang membuang kotorannya (tinja) di sembarang tempat dapat membuat penularan penyakit diare melalui air maupun vektor.

Berdasarkan hasil survei awal yang dilakukan peneliti dengan menggunakan metode wawancara pada 7 orang tua balita, peneliti menemukan 4 dari 7 orang tua balita yang tidak memahami gejala dan penyebab diare, kemudian terkait penyediaan air bersih 4 dari 7orang tua balita mengatakan kesulitan air bersih dan 4 dari 7 orang tua mengatakan lebih sering membuang tinja ke laut atau meminjam WC tetangga karena belum memiliki jamban keluarga sendiri.

Berdasarkan latar belakang penulis tertarik melakukan penelitian di wilayah pesisir Kelurahan Lapulu Kecamatan Abeli karena adanya kasus diare di wilayah Kelurahan Lapulu sebanyak 41 kasus diare pada periode januari-juni, serta masih adanya masyarakat yang tidak memahami penyebab diare dan masih adanya masyarakat yang belum memiliki jamban dan kesulitan air bersih. Dengan alasan tersebut peeneliti bertujuan melakukan penelitian yangberjudul "Faktor-faktor yang berhubungan dengan kejadian diare pada Balita di wilayah Pesisir Kelurahan Lapulu Kecamatan Abeli Kota Kendari”.

\section{BAHAN DAN METODE}

Penelitian ini merupakan penelitian analitik observasional dengan rancangan Cross Sectional Study. Penelitian ini dilaksanakan di Wilayah Pesisir Kelurahan Lapulu Kecamatan Abeli kota Kendari. Populasi dalam penelitian ini adalah seluruh ibu yang memiliki anak balita 1-5 tahun yang tinggal di Wilayah Pesisir Kelurahan Lapulu Kecamatan Abeli Kota Kendari berjumlah 96 KK. Sampel dalam penelitian ini berjumlah 49 responden, yang diambil dengan menggunakan teknik Simple Random Sampling. Instrumen yang digunakan dalam penelitian ini adalah lembar kuesioner. Analisis data dilakukan dengan menggunakan Analisis bivariat dengan uji Chi-Square dan uji Phi. Data yang sudah diolah kemudian disajikan dalam bentuk tabel distribusi yang disertai dengan narasi.

\section{HASIL PENELITIAN}

Karakteristrik responden ibu meliputi kelompok umur, pekerjaan dan pendidikan terakhir diWilayah Pesisir Kelurahan Lapulu 
Kecamatan Abeli Kota Kendari yang disajikan pada Tabel 1 menunjukkan bahwa dari 49 responden ibu kelompok umur terbanyak yaitu kelompok umur 36-45 tahun berjumlah 27 responden $(55,1 \%)$ dan terkecil kelompok umur $>45$ tahun berjumlah 6 responden $(12,2 \%)$. Kemudian karakteristrik responden ibu berdasarkan pekerjaan menunjukkan bahwa dari 49 responden pekerjaan terbanyak yaitu wiraswasta berjumlah 17 responden $(34,7 \%)$ dan terkecil ibu rumah tangga berjumlah 7 responden(14,3\%).

Tabel 1. Karakteristik Responden

\begin{tabular}{ccc}
\hline Karakteristik & n (49) & \% \\
\hline $\begin{array}{c}\text { Kelompok Umur } \\
\text { (Tahun) }\end{array}$ & & \\
$1-2$ & 24 & 49,0 \\
$3-4$ & 21 & 42,9 \\
5 & 4 & 8,2 \\
\hline
\end{tabular}

\begin{tabular}{ccc}
\hline $\begin{array}{c}\text { Kelompok Umur } \\
\text { KK (Tahun) }\end{array}$ & & \\
$26-35$ & 16 & 32,7 \\
$36-45$ & 27 & 55,1 \\
$>45$ & 6 & 12,2 \\
\hline Jenis kelamin & & \\
Laki-laki & 19 & 38,8 \\
Perempuan & 30 & 61,2 \\
\hline Pendidikan & & \\
SD & 5 & 10,2 \\
SMP & 4 & 8,2 \\
SMA & 32 & 65,3 \\
Perguruan tinggi & 8 & 16,3 \\
\hline Pekerjaan & & \\
PNS/TNI/POLRI & 12 & 24,5 \\
Wiraswasta & 17 & 34,7 \\
Karyawan swasta & 13 & 26,5 \\
Ibu rumah tangga & 7 & 14,3 \\
\hline
\end{tabular}

Sumber : Data Primer, 2019

Tabel 1 menunjukkan bahwa karakteristrik balita berdasarkan kelompok umur dan jenis kelamin di Wilayah Pesisir Kelurahan Lapulu Kecamatan Abeli Kota Kendari ditemukan 49 balita kelompok umur terbanyak yaitu kelompok umur 1-2 tahun berjumlah 24 responden $(49,0 \%)$ dan terkecil kelompok umur 5 tahun berjumlah 4 responden $(8,2 \%)$. Kemudian karakteristrik balita berdasarkan jenis kelamin ditemukan 49 balita sebagian besar jenis kelamin perempuan berjumlah 30 responden $(61,2 \%)$ dan jenis kelamin laki-laki berjumlah 19 responden $(38,8 \%)$.

Tabel 2. Analisis Univariat

\begin{tabular}{ccc}
\hline Variabel & n (49) & \% \\
\hline Kejadian Diare & & \\
Diare & 29 & 59,2 \\
Tidak Diare & 20 & 40,8 \\
\hline Pengetahuan & & \\
Kurang & 31 & 63,3 \\
Cukup & 18 & 36,7 \\
\hline
\end{tabular}

\begin{tabular}{lll}
$\begin{array}{c}\text { Penyediaan Air } \\
\text { Bersih }\end{array}$ & & \\
Tidak memenuhi & 26 & 53,1 \\
$\quad$ syarat & & 46,9 \\
Memenuhi syarat & 23 & \\
\hline $\begin{array}{l}\text { Jamban Keluarga } \\
\text { Tidak memenuhi } \\
\quad \text { syarat }\end{array}$ & 23 & 46,9 \\
Memenuhi syarat & 26 & 53,1 \\
\hline Sumber : Data Primer, 2019 &
\end{tabular}

Hasil analisis univariat meliputi kejadian diare, pengetahuan, penyediaan air bersih dan jamban keluarga diWilayah Pesisir Kelurahan Lapulu Kecamatan Abeli Kota Kendari pada Tabel 2 menunjukkan bahwa dari 49 responden terdapat $29(59,2 \%)$ yang menderita diare dan $20(40,8 \%)$ yang tidak menderita diare. Sedangkan pada variabel pengetahuan ditemukan 49 responden yang memiliki pengetahuan dalam kategori kurang berjumlah 31 responden $(63,3 \%)$ dan yang memiliki pengetahuan dalam kategori cukup berjumlah 18 responden $(36,7 \%)$. Kemudian pada variabel penyediaan air bersih ditemukan 49 responden yang memiliki penyediaan air bersih tidak memenuhi syarat berjumlah 26 
responden $(53,1 \%)$ dan yang memiliki peyediaan air bersih memenuhi syarat berjumlah 23 responden (46,9\%). Pada variabel jamban keluarga dari 49 responden yang memiliki jamban keluarga memenuhi syarat 26 responden $(53,1 \%)$ dan yang memiliki jamban keluarga tidak memenuhi syarat berjumlah 23 responden (46,9\%).

Hasil analisis bivariat mengenai hubungan variabel independen dengan variabel dependen dapat dilihat pada tabel 3 menunjukkan bahwa dari 49 responden, hubungan pengetahuan dengan kejadian diare pada anak balita di Wilayah Pesisir Kelurahan Lapulu Kecamatan Abeli Kota Kendari pengetahuan cukup berjumlah 18 responden $(36,7 \%)$, yang menderita diare berjumlah 6 responden $(12,2 \%)$ dan tidak menderita diare berjumlah 12 responden $(24,5 \%)$. Sedangkan responden yang pengetahuan kategori kurang berjumlah 31 responden $(63,3 \%)$, yang menderita diare berjumlah 23 responden $(46,9 \%)$ dan tidak menderita diare berjumlah 8 responden (16,3\%).Berdasarkan hasil uji ChiSquare diperoleh nilai $p$-value $=0,012$, dimana nilai tersebut lebih kecil dari nilai $\alpha$ $(0,05)$, ini berarti bahwa ada hubungan antara pengetahuan dengan kejadian diare pada anak balita di wilayah pesisir Kelurahan Lapulu Kecamatan Abelia Kota Kendari. Hasil uji keeratan hubungan memperoleh nilai Phi 0,401 yang berarti ada hubungan sedang antara pengetahuan dengan kejadian diare pada anak balita di wilayah pesisir Kelurahan Lapulu Kecamatan Abeli Kota Kendari.
Tabel 3 menunjukkan bahwa dari 49 responden, responden yang penyediaan air bersih kategori memenuhi syarat sebanyak 23 responden $(46,9 \%)$, yang menderita diare sebanyak 8 responden $(16,3 \%)$ dan tidak menderita diare sebanyak 15 responden (30,6\%0. Sedangkan responden yang penyediaan air bersih kategori tidak memenuhi syarat sebanyak 26 responden $(53,1 \%)$, yang menderita diare sebanyak 21 responden $(42,9 \%)$ dan tidak menderita diare sebanyak 5 responden (10,2\%).Berdasarkan hasil uji ChiSquare di peroleh nilai $p$-value $=0,003$, dimana nilai tersebut lebih kecil dari nilai $\alpha$ $(0,005)$, ini berarti bahwa ada hubungan antara penyediaan air bersih dengan kejadiaan diare pada anak balita di wilayah pesisir kelurahan lapulu kecamatan abelia kota kendari. Hasil uji keeratan hubungan memperoleh nilai Phi 0,467 yang berarti ada hubungan sedang antara penyediaan air bersih dengan kejadian diare pada anak balita di wilayah pesisir Kelurahan Lapulu Kecamatan Abeli Kota Kendari.

Tabel 3 menunjukkan bahwa dari 49 responden, responden yang memiliki jamban memenuhi syarat 26 responden $(53,1 \%)$, yang menderita diare sebanyak 10 responden $(20,4 \%)$ dan tidak menderita sebanyak 16 responden $(32,7 \%)$. Sedangkan responden yang memiliki jamban tidak memenuhi syarat sebanyak 23 responden (46,9\%), yang menderita diare sebanyak 19 responden $(38,8 \%)$ dan tidak menderita diare sebanyak 4 responden 8,2\%).Berdasarkan hasil uji ChiSquare di peroleh nilai $p$-value $=0,004$, dimana nilai tersebut lebih kecil dari nilai $\alpha$ 
Tabel 3. Analisis Bivariat

\begin{tabular}{|c|c|c|c|c|c|c|c|}
\hline \multirow{3}{*}{ Variabel } & \multicolumn{4}{|c|}{ Kejadian Diare } & \multicolumn{2}{|c|}{ Total } & \multirow{3}{*}{$\begin{array}{c}\text { Hasil Uji Chi- } \\
\text { Square }\left(\mathbf{X}^{2}\right)\end{array}$} \\
\hline & \multicolumn{2}{|c|}{ Menderita } & \multicolumn{2}{|c|}{ Tidak Menderita } & \multirow[b]{2}{*}{$\mathbf{n}$} & \multirow[b]{2}{*}{$\%$} & \\
\hline & $\mathbf{n}$ & $\%$ & $\mathbf{n}$ & $\%$ & & & \\
\hline \multicolumn{8}{|l|}{ Pengetahuan } \\
\hline Kurang & 23 & 46,9 & 8 & 16,3 & 31 & 63,3 & \multirow{2}{*}{$\begin{array}{c}\text { Pvalue }=0,012 \\
\text { Phi } 0,401\end{array}$} \\
\hline Cukup & 6 & 12,2 & 12 & 24,5 & 18 & 36,7 & \\
\hline \multicolumn{8}{|l|}{ Penyediaan Air Bersih } \\
\hline Tidak Memenuhi Syarat & 21 & 42,9 & 5 & 10,2 & 26 & 53,1 & \multirow{2}{*}{$\begin{array}{c}\text { Pvalue }=0,003 \\
\text { Phi } 0,467\end{array}$} \\
\hline Memenuhi Syarat & 8 & 16,3 & 15 & 30,6 & 23 & 46,9 & \\
\hline \multicolumn{8}{|l|}{ Jamban Keluarga } \\
\hline Tidak Memenuhi Syarat & 19 & 38,8 & 4 & 8,2 & 23 & 46,9 & \multirow{2}{*}{$\begin{array}{c}\text { Pvalue }=0,004 \\
\text { Phi } 0,448\end{array}$} \\
\hline Memenuhi Syarat & 10 & 20,4 & 16 & 32,7 & 26 & 53,1 & \\
\hline
\end{tabular}

Sumber : Data Primer, 2019

$(0,005)$, ini berarti bahwa ada hubungan antara jamban keluarga dengan kejadiaan diare pada anak balita di Wilayah Pesisir Kelurahan Lapulu Kecamatan Abeli Kota Kendari. Hasil uji keeratan hubungan memperoleh nilai $P h i$ 0,448 yang berarti ada hubungan sedang antara ketersediaan jamban keluarga dengan kejadian diare pada anak balita di wilayah pesisir Kelurahan Lapulu Kecamatan Abeli Kota Kendari.

\section{PEMBAHASAN}

Pengetahuan merupakan hasil dari tahu, dan ini terjadi setelah orang melakukan penginderaan terhadap suatu objek tertentu. Penginderaan terjadi melalui panca indera manusia yakni indra penglihatan, pendengaran, penciuman, rasa dan raba. Sebagian besar pengetahuan manusia diperoleh melalui mata dan telinga. Berdasarkan hasil uji univariat menunjukkan bahwa dari 49 responden (100\%), dimana responden yang memiliki pengetahuan dalam kategori cukup sebanyak 18 responden $(36,7 \%)$, dan responden yang memiliki pengetahuan kurang sebanyak 31 responden
$(63,3 \%)$. Hal ini dikarenakan kurangnya pemahaman masyarakat di wilayah pesisir Kelurahan Lapulu mengenai gejala penyakit diare pada anak balita, sehingga kasus penyakit diare diwilayah tersebut masih sangat tinggi walaupun masyarakatnya memiliki ratarata tingkat pendidikan yang cukup tinggi.

Berdasarkan hasil uji bivariat menunjukkan bahwa dari 49 responden (100\%), Responden yang pengetahuan kategori cukup sebanyak 18 responden $(36,7 \%)$, dan yang menderita diare sebanyak 6 responden, hal ini disebabkan responden belum memiliki jamban keluarga kategori memenuhi syarat sehingga timbul perilaku membuang tinja sembarang tempat seperti sungai,laut,dan sebagainya. Sedangkan responden yang pengetahuan kategori kurang sebanyak 31 responden $(63,3 \%)$, dan terdapat 8 responden $(16,3 \%)$ hal ini disebabkan karena kebanyakan responden menkonsumsi air minum yang belum dimasak terlebih dahulu.

$$
\text { Menurut Notoatmodjo }
$$
pendidikan kesehatan pada hakikatnya adalah suatu kegiatan atau usaha untuk menyampaikan pesan kesehatan kepada 
masyarakat, kelompok atau individu dengan harapan bahwa dengan adanya pesan tersebut masyarakat, kelompok atau individu dapat memperoleh pengetahuan tentang kesehatan yang lebih baik. Akhirnya pengetahuan tersebut diharapkan dapat berpengaruh terhadap perubahan perilakunya. ${ }^{6}$. Pengetahuan sangat berperan dalam terbentukan tindakan seeorang. Dengan demikian pengetahuan yang rendah akan berdampak kepada perilaku seseorang dalam kehidupan sehari-hari termasuk dalam upaya pencegahan penyakit ${ }^{7}$.

Air bersih adalah air yang digunakan untuk keperluan sehari-hari yang kualitasnya memenuhi syarat kesehatan dan dapat diminum apabila telah di masak. Air sebagai salah satu media transmisi penyakit, karena itu perlu untuk diawasi kualitasnya agar nilainya tetap sesuai standar baku mutu kesehatan agar penularan penyakit melalui air dapat dicegah dan dibilangkan.

Berdasarkan hasil uji univariat, menunjukkan bahwa dari 49 responden, yang memiliki penyediaan air bersih tidak memenuhi syarat berjumlah 26 responden $(53,1 \%)$ dan yang memiliki peyediaan air bersih memenuhi syarat berjumlah 23 responden (46,9\%). Hal ini karena sumber air yang masih digunakan oleh warga yang kebanyakan menggunakan PDAM memiliki kualitas air yang tidak memenuhi syarat, yang bersih dari segi faktor fisik yang meliputi warna, bau, dan rasa.Kemudian jarak sumber air dari septic tank warga sangat dekat sehingga bakteri-bakteri patogen dapat dengan mudah masuk ke sumber air tersebut.
Berdasarkan hasil penelitian menunjukkan bahwa dari 49 responden (100\%), responden yang memiliki penyediaan air bersih memenuhi syarat sebanyak 23 responden (46\%), dan terdapat 8 responden $(30,6 \%)$ yang menderita diare. Hal ini karena pengetahuan responden yang masih kurang serta kurangnya informasi dan penyuluhan dari pihak puskesmas untuk menyampaikan faktor penyebab diare, sehingga responden tidak mengetahui faktor penyebab diare. Sedangkan responden yang penyediaan air bersih kategori tidak memenuhi syarat sebanyak 26 responden $(42,9 \%)$ dan tidak menderita diare sebanyak 5 responden $(10,2 \%)$. Hal ini karena walaupun memiliki sumber air yang tidak memenuhi syarat, responden cukup memahami dampak bagi kesehatan bagi balita dari menkonsumsi air tersebut.

Sumber air minum utama merupakan salah satu sarana sanitasi yang tidak kalah pentingnya berkaitan dengan kejadian diare. Sebagian kuman infeksius penyebab diare ditularkan melalui jalur fekal oral. Mereka dapat ditularkan dengan memasukkan ke dalam mulut, cairan atau benda yang tercemar dengan tinja, misalnya air minum, jari-jari tangan, dan makanan yang disiapkan dalam panci yang dicuci dengan air tercemar. ${ }^{8}$

Hasil analisis dan pembahasan maka penulis menarik kesimpulan bahwa penyediaan air bersih sangatlah penting untuk itu penulis sarankan pada masyarakat yang penampungan air bersihnya telah cukup bersih senantiasa di pertahankan dan di tingkatkan lagi dan bagi masyarakat yang tempat penampungan air bersihnya masih kurang agar 
senantiasa rutin membersihkannya seminggu sekali agar supaya air yang digunakan dalam kegiatan sehari-hari keluarga selalu bersih sehingga tidak menjadi penyebab anggota keluarga terkena diare.

Setiap rumah hendaknya mempunyai jamban sendiri yang merupakan salah satu hal penting dalam usaha pemeliharaan kesehatan lingkungan. Dalam pengertiannya jamban keluarga adalah suatu bangunan yang di gunakan untuk membuang dan mengumpulkan kotoran /najis manusia yang lasim disebut kakus/wc,sehingga kotoran najis tersebut tersimpan dalam suatu tempat tertentu dan tidak menjadi penyebab atau penyebar penyakit dan mengotori lingkungan pemukiman. Berdasarkan hasil uji univariat menunjukkan bahwa dari 49 responden, yang memiliki jamban keluarga memenuhi syarat 26 responden $(53,1 \%)$ dan yang memiliki jamban keluarga tidak memenuhi syarat berjumlah 23 responden $(46,9 \%)$. Hal ini karena masih banyak masyarakat di Wilayah Pesisir Kelurahan Lapulu membuang tinja langsung ke laut.

Berdasarkan hasil bivariat menunjukkan bahwa dari 49 responden (100\%), responden yang jamban keluarganya kategori memenuhi syarat sebanyak 26 responden $(53,1 \%)$, dan yang menderita diare sebanyak 10 responden $(20,4 \%)$. Hal ini karena responden memiliki sumber air yang tidak memenuhi syarat yang memiliki letak kurang dari 10 meter dari septic tank warga sekitar. Sedangkan responden yang memiliki jamban keluarga dalam kategori tidak memenuhi syarat sebanyak 23 responden $(46,9 \%)$, dan yang tidak menderita diare sebanyak 4 responden $(8,2 \%)$. Hal ini karena responden sangat memperhatikan kebersihan makanan dan minuman yang dikonsumsi oleh balitanya walaupun memiliki jamban keluarga yang tidak memenuhi syarat dan dapat menjadi sumber bakteri penyebeb penyakit diare.

Hasil penelitian ini sejalan dengan hasil penelitan yang dilakukan oleh Lilis Steven dimana diketahui adanya hubungan antara kepemilikan jamban dengan kejadian diare dengan hasil uji statistik yang signifikan dengan $p$-value $=0,003$ dimana nilai tersebut lebih kecil dari nilai $\alpha(0,05) .{ }^{9}$ Hasil penelitian ini juga didukung oleh penelitian lain yang dilakukan pula di Kawasan Pesisir di Kota Kendari Tahun 2017 terkait faktor sanitasi yang berhubungan dengan kejadian Diare. Penelitian tersebut menunjukkan bahwa ada hubungan yang kuat antara jamban keluarga dengan kejadian Diare. ${ }^{10}$

Hasil analisis dan pembahasan maka penulis berasumsi bahwa jamban sangat diperlukan bagi usaha mempertahankan kesehatan dari penyakit diare. Untuk itu penulis sarankan agar masyarakat membuat jamban keluarga yang memenuhi kesehatan serta mengajarkan kepada seluruh anggota keluarga agar manfaatkan jamban sehingga dapat memutus rantai penularan penyakit diare sehingga anggota keluarga tidak mudah terserang penyakit Diare.

\section{KESIMPULAN DAN SARAN}

Berdasarkan hasil penelitian dan pembahasan maka dapat ditarik kesimpulan 
bahwa ada hubungan sedang antara pengetahuan, penyediaan air bersih, dan kepemilikan jamban keluarga dengan kejadian penyakit diare pada masyarakat kawasan pesisir Kelurahan Lapulu Kecamatan Abeli Kota Kendari.

Berdasarkan kesimpulan yang telah diuraikan di atas, maka saran yang dapat diberikan: Pertama, untuk masyarakat di Wilayah Pesisir Kelurahan Lapulu Kota Kendari, agar lebih memperhatikan asupan makanan dan minuman untuk anak balita. Kedua, untuk pihak puskesmas agar memberikan sosialisasi mengenai penyebab dan cara pencegahan penyakit diare pada balita, sehingga dapat terhindar dari penyakit diare. Ketiga, untuk pemerintah agar lebih memperhatikan ketersediaan air bersih yang terdapat pada masyarakat sehingga penyakit diare yang ditimbulkan akibat kurangnya kualitas penyediaan air bersih yang terdapat pada masyarakat dapat dihindari. Keempat, untuk peneliti selanjutnya diharapkan dapat melakukan penelitian yang serupa dengan data yang lebih spesifik dengan variabel yang berbeda seperti status gizi penderita diare dan makanan yang dikonsumsi penderita sebelum dan sesudah diare.

\section{DAFTAR PUSTAKA}

1. Hartati S, Nurazila. Faktor yang Mempengaruhi Kejadian Diare Pada Balita di Wilayah Kerja Puskermas Rejosari Pekanbaru. Jurnal Kesehatan Masyarakat. 2018;3(2):400-407.
2. WHO. Diarrhea: Why Children are Still Dying and What Can be Done. Geneva; 2009.

3. Kemenkes RI. Standar Antropomentri Penilaian Gizi Anak. Jakarta; 2011.

4. Dinas Kesehatan Provinsi Sulawesi Tenggara. Profil Kesehatan Provinsi Sulawesi Tenggara Tahun 2018. Kota Kendari; 2019.

5. Puskesmas Abeli. Profil Puskesmas Abeli Tahun 2018. Kota Kendari; 2019.

6. Notoatmodjo S. Ilmu Kesehatan Masyarakat (Prinsip-Prinsip Dasar). Jakarta: Rineka Cipta; 2003.

7. Fadmi FR. Perbandingan Tingkat Pengetahuan Sebelum dan Sesudah Penyuluhan Kesehatan Tentang Penyakit Scabies Pada Santri Kelas VII Pondok Pesantren Darul Mukhlisis. Jurnal Kesehatan Preventif. 2019;9(8):68-102.

8. Depkes RI. Panduan Sosialisasi Tatalaksana Diare Balita. Jakarta; 2011.

9. Steven L, Azizah R. Hubungan Sanitasi Dasar Rumah Dengan Kejadian Diare di Desa Bina Nusa Tenggara Timur. Jurnal Kesehatan Lingkungan. 2013;1(2):1-9.

10.Saparina T. Hubungan Sanitasi Lingkungan dengan Kejadian Penyakit Diare pada Masyarakat Kawasan Pesisir Kelurahan Lapulu Kecamatan Abeli Kota Kendari. Jurnal Kesehatan Preventif. 2018;8(7):1-13. 